Ambiente \& Água - An Interdisciplinary Journal of Applied Science
ISSN 1980-993X - doi:10.4136/1980-993X
www.ambi-agua.net
E-mail: ambi.agua@gmail.com

\title{
Changes in physicochemical and toxicological parameters of waters of Trincheira's River caused by road construction
}

\author{
ARTICLES doi:10.4136/ambi-agua.2360
}

Received: 17 Dec. 2018; Accepted: 08 May 2019

\author{
Juan Camilo Pires Salcedo Restrepo' ${ }^{1 D}$; Danieli Iara Antonelo ${ }^{2}$; \\ Ticiane Sauer Pokrywiecki $^{1}$; Ivane Benedetti Tonial $^{3}{ }^{(D}$; Fernando César Manosso ${ }^{1}{ }^{(D}$; \\ Igor Vivian de Almeida ${ }^{4}$; ; Veronica Elisa Pimenta Vicentini ${ }^{4}{ }^{\circledR}$; Elisângela Düsman $^{3 *(i)}$ \\ ${ }^{1}$ Universidade Tecnológica Federal do Paraná (UTFPR), Francisco Beltrão, PR, Brasil \\ Departamento Acadêmico de Engenharia Ambiental (DAEAM). E-mail: juan_cps_restrepo@hotmail.com, \\ ticiane@utfpr.edu.br,fmanosso@utfpr.edu.br \\ ${ }^{2}$ Universidade Tecnológica Federal do Paraná (UTFPR), Francisco Beltrão, PR, Brasil \\ Departamento Acadêmico de Engenharia Química (DAENQ). E-mail: dani_eli.antonelo@hotmail.com \\ ${ }^{3}$ Universidade Tecnológica Federal do Paraná (UTFPR), Francisco Beltrão, PR, Brasil \\ Departamento Acadêmico de Química e Biologia (DAQBI). \\ E-mail: ivane@utfpr.edu.br, edusman@utfpr.edu.br \\ ${ }^{4}$ Universidade Estadual de Maringá (UEM), Maringá, PR, Brasil \\ Departamento de Biotecnologia, Genética e Biologia Celular (DBC). \\ E-mail: igoralmeida.bio@gmail.com, arbvepv@wnet.com.br \\ "Corresponding author
}

\begin{abstract}
Road infrastructures can greatly affect natural areas. A trench and a roundabout were constructed in the city of Francisco Beltrão-Paraná-Brazil over a water body called Trincheira's River. The present study evaluated the quality of the waters of Trincheira's River, in physicochemical and toxicological terms, at four points along its course, during and after the trench and the roundabout construction. The results of the physicochemical analysis showed changes in some parameters analyzed near the road infrastructure, in particular, oils and greases, biochemical oxygen demand and dissolved oxygen. The immobility/mortality test with Artemia salina L. micro shellfish showed that none of the water at the collection points of the river was toxic. The cytotoxicity test with the bioindicator Allium cepa L. revealed no cytotoxic effect in the sample collection done during the road construction. However, after the finalization of the trench and the roundabout construction, a statistically significant increase in the percentage of the mitotic index at the road construction point was noticed. Therefore, awareness and regulatory measures are necessary to oversee activities on water bodies' shores and environs, to ensure a harmonious relationship between human activity and the ecosystem.
\end{abstract}

Keywords: Allium cepa L., Artemia salina L., bioindicators, water pollution, water quality.

\section{Alterações dos parâmetros físico-químicos e toxicológicos das águas do Rio da Trincheira afetadas por uma construção rodoviária}

\section{RESUMO}

Infraestruturas rodoviárias podem afetar áreas naturais com grande intensidade. Um trevo e uma trincheira foram construídas na cidade de Francisco Beltrão-Paraná-Brasil sobre um 
corpo d'água chamado Rio da Trincheira. O objetivo do presente estudo foi avaliar a qualidade de suas águas, em termos físico-químicos e toxicológicos, em quatro pontos ao longo de seu curso, durante e após a construção da trincheira e do trevo. Os resultados das análises físicoquímicas mostraram alterações em alguns parâmetros analisados, em especial, óleos e graxas, demanda bioquímica de oxigênio e oxigênio dissolvido, próximos à infraestrutura rodoviária. O teste de imobilidade/mortalidade com os microcrustáceos Artemia salina L. mostrou que nenhum dos pontos de coleta de água do rio foi tóxico. O teste de citotoxicidade com o bioindicador Allium cepa L. revelou que não houve efeito citotóxico na coleta da amostra durante a construção rodoviária. No entanto, após a finalização da construção da trincheira e do trevo, verificou-se um aumento estatisticamente significativo da percentagem do índice mitótico no ponto/local de construção da estrada. Portanto, medidas de conscientização e regulação devem ser necessárias para interferir nas atividades realizadas nas margens e nos corpos d'água, buscando uma relação harmoniosa entre as atividades humanas e todo o ecossistema.

Palavras-chave: Allium cepa L., Artemia salina L., bioindicadores, poluição da água, qualidade da água.

\section{INTRODUCTION}

Disorganized demographic growth, combined with a lack of urban planning and the irregular handling of agricultural products, can promote the degradation of water bodies. Buildings in general, but especially road infrastructures, affect natural areas with greater intensity than other processes of development, since they can lead to accidental spillages of chemical waste in rivers (Moraes and Santos, 2004), contaminating waters.

Solid or liquid waste from urban development, as well as from construction and demolition, has been the focus of studies in the past few years due to the environmental damage that they can cause. With regard to environmental damage, the lack of supervision of urban civil works and roads tends to worsen the impacts, compromising the quality not only of the soil and air but also of water bodies near urban facilities.

The pollution of a headwater mainly affects the physicochemical characteristics of the water, then systematically destroys the aquatic community, compromising the trophic chain and public health. However, the exclusive use of physical or physicochemical parameters to assess water quality (Von Sperling, 2005) has attracted criticism, in that a more ecosystemic approach is needed, requiring the application of biological assessment studies (Kuhlmann et al., 2001).

Bioindicators respond efficiently to the presence or absence of a contaminant, providing data related to the conditions of a specific environment (Frontalini and Coccioni, 2011). In Brazil, aquatic ecotoxicology has been used, along with chemical and physicochemical parameters, as a water quality parameter, constituting an important monitoring instrument of water resources (Tavares, 2014). In this sense, while chemical analyses identify and quantify concentration of toxic substances, toxicity tests assess the effect of these substances on biological systems.

Luíz et al. (2012) recommends that the toxic effect of a sample be evaluated by more than one representative species of aquatic biota, preferably belonging to different trophic levels of the food chain. In this scenario, the immobility/mortality test with Artemia salina L. micro shellfish and cytotoxicity test with the vegetable Allium cepa L. stand out. The test with A. salina is a method that has a good correlation with acute oral toxicity tests in vivo (Silva et al., 2010). Similarly, the test with A. cepa could be sensitive, and in addition has a positive correlation in prokaryotes and eukaryotes (Fatma et al., 2018), being indicative of risk to human health or the environment.

Rev. Ambient. Água vol. 14 n. 4, e2360 - Taubaté 2019 
Hence, the present study evaluated, through physicochemical analysis and ecotoxicological tests with A. salina and $A$. cepa, the influence of urban construction activities on the water quality of Trincheira's River in the municipality of Francisco Beltrão - Paraná, Brazil.

\section{MATERIAL AND METHODS}

\subsection{Study Area}

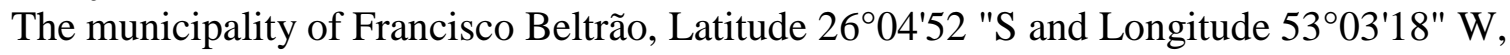
located in the southwest region of the State of Paraná - Brazil (Figure 1), is undergoing urban expansion (Francisco Beltrão, 2012).

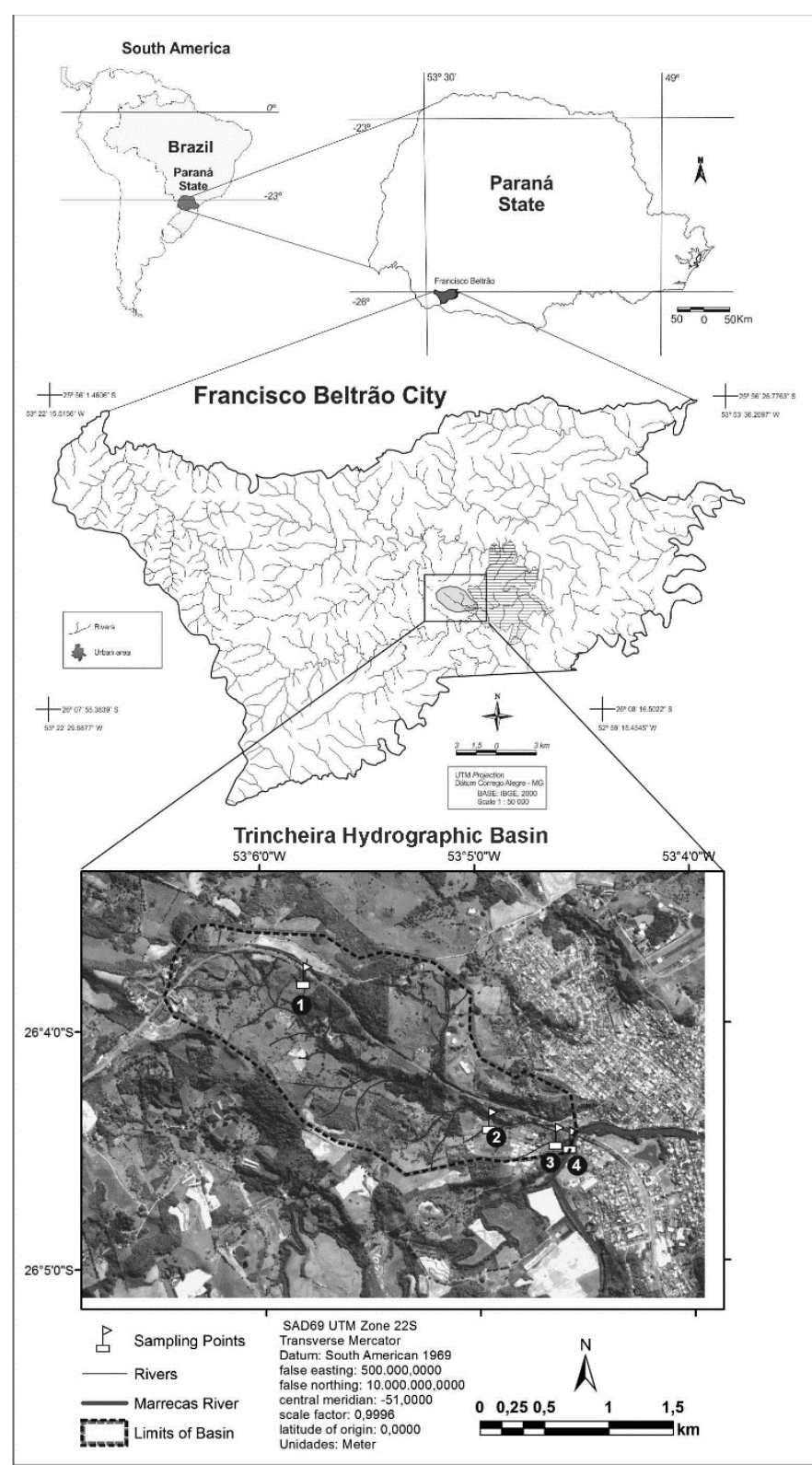

Figure 1. Location of the municipality of Francisco Beltrão-Paraná, Brazil. The river basin area contributing to the river headwater contribution of Trincheira's River (area under study) and its water-sample collection points: River headwater (P1); Residential condominium (P2); Place where the river was channeled for road construction (P3); River mouth (P4). 
The region of the study (the watershed basin of the Trincheira's River) is characterized by agricultural, urban and industrial activities, with an emphasis on beef and dairy cattle, construction of residential condominiums and mining. This headwater has a significant importance to the region, since it supplies the small farms for livestock watering, aquaculture, and even human consumption. In order to facilitate access to the county, a trench and roundabout were built, at the same place, in the West region of the municipality. This required rock demolition, as well as earth work and the insertion of a drain pipeline, to conduct the water of the Trincheira's River, the course of which was changed close to its mouth at Marrecas's river.

The daily flow of trucks (cargo/transport), buses (urban, intermunicipal and state), agricultural machinery and other automobiles is intense. The roundabout directs the flow of vehicles to an industrial district, the federal university, the agricultural school and the other neighborhoods around the city.

\subsection{Sampling}

The water samples were collected during October 2014 and after April 2015, the trench and the roundabout construction. In October 2014, the total monthly rainfall was approximately 125 millimeters, and in April 2015 it was 45 millimeters in the city of Francisco Beltrão and the surrounding region (IAPAR, 2016).

Four sampling points were selected along Trincheira's River (Figure 1): Point 01 Headwater of the river $\left(6^{\circ} 03^{\prime} 46.4^{\prime \prime} \mathrm{S} ; 53^{\circ} 05^{\prime} 50.3^{\prime \prime} \mathrm{W}\right)$; Point 02 - Next to a residential condominium $\left(26^{\circ} 04^{\prime} 23.9^{\prime \prime} \mathrm{S} ; 5^{\circ} 04^{\prime} 56.2^{\prime \prime} \mathrm{W}\right)$; Point 3 - The trench and the roundabout construction $\left(26^{\circ} 04^{\prime} 27.5^{\prime \prime} \mathrm{S} ; 5^{\circ} 04^{\prime} 37.9^{\prime \prime} \mathrm{W}\right)$; and Point 04 - The river mouth (26 $04^{\prime} 29.3^{\prime \prime} \mathrm{S}$; $\left.53^{\circ} 04^{\prime} 37.2^{\prime \prime} \mathrm{W}\right)$.

The collection and preservation/storage of water samples were carried out according to instructions and methods contained in "Standard Methods" (APHA et al., 2012). The samples were collected with the aid of a plastic bucket, in places of difficult access to the middle of the river water stream, and stored in clean plastic bottles. Where possible, the plastic bottles were immersed at the point of collection in the river, about $30 \mathrm{~cm}$ deep. The parameters of $\mathrm{pH}$, Temperature (T), chemical oxygen demand (COD), biochemical oxygen demand (BOD) and dissolved oxygen (DO) were analyzed in the laboratory immediately after collection. For the analysis of ammonia nitrogen, total phosphorus, oils and greases and toxicity, the bottles with samples were stored in a refrigerator at $10^{\circ} \mathrm{C}$ for up to 1 week or frozen $\left(\mathrm{T} \leq 4^{\circ} \mathrm{C}\right)$ for subsequent analysis. Afterwards, the bottles were thawed until they reached room temperature.

\subsection{Physicochemical parameters}

The analysis of physicochemical parameters of the water samples of the Trincheira's River followed the methodologies established by the "Standard Methods" (APHA et al., 2012). The following parameters were evaluated in triplicate: $\mathrm{pH}$, chemical oxygen demand, biochemical oxygen demand, dissolved oxygen, ammoniacal nitrogen (ammonia-N), total phosphorus, oils and greases and temperature.

\subsection{Immobility/Mortality tests}

The toxicity test was performed with A. salina L. by the method proposed by Guerra (2001), with modifications based on ABNT NBR 13373 (2010). Ten nauplii of A. salina, in instar stages 2-3, were transferred to test tubes containing $2 \mathrm{~mL}$ of samples from the different points of Trincheira's River, and diluted in a saline solution ( $30 \mathrm{~g}$ of sea salt per L distilled water) in the following concentrations: $100 \%, 50 \%, 25 \%, 12.5 \%, 6.2 \%$ and $3.1 \%$, in order to determine the critical range, based on the average number of dead nauplii per concentration of the river's water, based on ABNT NBR 13373 (2010). The negative control group contained only $2 \mathrm{~mL}$ 
of saline solution $\left(\mathrm{CO}^{-} 1\right)$ or $2 \mathrm{~mL}$ of mineral water $\left(\mathrm{CO}^{-} 2\right)$, to confirm the effect of river water and not saline or sweet. Positive control $\left(\mathrm{CO}^{+}\right)$was performed with $0.016 \mu \mathrm{L}$ of methyl methanesulfonate per $\mathrm{mL}$ of mineral water. After 24 hours of incubation (tubes at $25 \pm 1{ }^{\circ} \mathrm{C}$ ), the number of dead/immobility nauplii was checked for each replicate to calculate the mean number of dead/immobile nauplii, thus determining the toxicity.

\subsection{Cytotoxicity and mutagenicity tests}

Cytotoxicity and mutagenicity tests were assessed using the meristematic cells of the root of $A$. серa L. (onion), prepared by the Feulgen reaction and stained with the Schiff reagent (Fiskesjö, 1985).

First, the onion bulbs were cleaned and placed to generate roots in containers containing filtered, aerated water, in a dark room, with temperature control of $25 \pm 2^{\circ} \mathrm{C}$. Five onions were used for each treatment sample group. Before each treatment, two roots of each onion were collected, to serve as the control of the bulb (Co-Oh). Thereafter, the roots were exposed to treatments with water samples from Trincheira's River and $0.04 \mathrm{mg}$ of cyclophosphamide/mL filtered water (positive control $-\mathrm{CO}^{+}$), for 24 hours $(\mathrm{Tr}-24 \mathrm{~h}$ ), according to the proposal proposed by Fiskesjö (1985). The bulbs were then placed again in filtered water, to recover themselves from any damage for 24 hours $(\mathrm{Re}-24 \mathrm{~h})$. The negative control $\left(\mathrm{CO}^{-}\right)$remained all the time in the filtered water.

The roots collected during the three days of collection $(\mathrm{Co}-0 \mathrm{~h}, \mathrm{Tr}-24 \mathrm{~h}, \mathrm{Re}-24 \mathrm{~h})$ of all treatments (Points 1, 2, 3, 4, $\mathrm{CO}^{+}$and $\mathrm{CO}^{-}$) were fixed, hydrolyzed with hydrochloric acid $(\mathrm{HCl}$ $1 \mathrm{~N}$ at $60^{\circ} \mathrm{C}$ for 10 minutes) and colored with Schiff reagent (45 minutes in the dark). Then, the meristematic region of onion roots was collected, stained with acetic orcein and crushed to produce the blades.

The blades were analyzed using the blind test in light microscopes $(40 \mathrm{x})$. One thousand cells were counted from each onion, differentiating them according to the mitotic phases (Interphase, Prophase, Metaphase, Anaphase, Telophase), to determine the percentage of Mitotic index (MI\%) from each sampling time of the evaluated groups, using the following formula: $\mathrm{MI} \%=$ (number of dividing cells/total number of cells analyzed) $\mathrm{x} 100$. The cells were also analyzed observing structural changes, like colchicine metaphase or disorganized metaphase, disorganized anaphase or with chromosomes loss, micronucleus and others.

\subsection{Statistical analysis}

The average of physicochemical analyses, the average of immobility (Immobility test) and the average of MIs (Cytotoxicity test) were performed by the Tukey test $(\alpha=0.05 ; n=3, n=4$ and $\mathrm{n}=5$, respectively).

\section{RESULTS AND DISCUSSION}

The $\mathrm{pH}$ values (Table 1) found in the river's water samples, although with a statistical difference $(\mathrm{p}<0.05)$ between points and also in the periods during and after the trench and roundabout construction, are in accordance with the limit (6.0-9.0) established by CONAMA legislation $\mathrm{N}^{\circ} 357$ (2005) for the class of Trincheira's River (Class II of fresh water). According to Von Sperling (2005), aquatic organisms are usually adapted to conditions of neutrality ( $\mathrm{pH}$ $\approx 7$ ), and sudden changes of the water's $\mathrm{pH}$ may lead to the extinction of aquatic biota. In the present study, $\mathrm{pH}$ ranged from 6.5 to 7.2 (slight acid to neutral), not being considered an abrupt variation (Avvannavar and Shrihari, 2008) or an endangering value to the aquatic ecosystem (Yalçuk and Postalcığlu, 2015). According to Gupta et al. (2017), the variations of pH can be attributed to the different seasons and climates of the year during the samplings, resulting in a variation in the concentration of $\mathrm{CO}_{2}$ incorporated in river waters. Similar $\mathrm{pH}$ values were obtained by Gan et al. (2008), to evaluate the $\mathrm{pH}$ of superficial water runoff of some sampling

Rev. Ambient. Água vol. 14 n. 4, e2360 - Taubaté 2019 
points on highways in the Pearl River Basin (Guangzhou-Southern China).

The concentration of total phosphorus (Table 1) also presented significant difference ( $\mathrm{p}<0.05$ ) when compared with the collecting points, during and after the ending of construction, with values that varied from $0.013(\mathrm{P} 1)$ to $0.033 \mathrm{mg} \mathrm{L}^{-1}(\mathrm{P} 2)$, being all values below what is recommended in the legislation (0.1 mg L-1) (CONAMA, 2005). The highest value for the concentration of phosphorus at Point 2 can be directly related to the $\mathrm{pH}$, because, according to Silva et al. (2003), lower values of $\mathrm{pH}$ favor the dissolution of substances, increasing their concentrations in the aqueous medium. Other factors that may explain the low phosphorus concentration along the river are the water's flow at the points of collection (lotic stretch), low incidence of rural residences and the absence of agricultural fields. According to Kibena et al. (2014) and Rahman et al. (2011), the increase in the concentrations of nutrients $\left(\mathrm{NO}_{3}, \mathrm{NH}_{3}\right.$, and $\left.\mathrm{PO}_{4}\right)$ in surface water bodies tends to be related to the presence of fertilizers, synthetic substances, domestic effluents and the decrease of the water's flow (lentic stretches).

Table 1. Average and standard deviation of physicochemical parameters analyzed in triplicate for the different points of the Trincheira's River, during and after road infrastructure construction.

\begin{tabular}{|c|c|c|c|c|c|}
\hline \multirow{2}{*}{$\begin{array}{l}\text { Collecting } \\
\text { Points }\end{array}$} & \multirow{2}{*}{$\begin{array}{c}\text { Time of } \\
\text { Collection }\end{array}$} & \multicolumn{4}{|c|}{ Physicochemical Parameters } \\
\hline & & pH & $\begin{array}{l}\text { Ammonia- } \\
\mathbf{N}\left(\mathrm{mg} \mathrm{L}^{-1}\right)\end{array}$ & $\begin{array}{c}\text { Total Phosphorus } \\
\left(\mathrm{mg} \mathrm{L}^{-1}\right)\end{array}$ & $\begin{array}{c}\text { Temperature } \\
\left({ }^{\circ} \mathrm{C}\right)\end{array}$ \\
\hline \multirow{2}{*}{ P1 } & During & $6.64 \pm 0.01^{\mathrm{aA}}$ & VA & $0.016 \pm 0.001^{\mathrm{aA}}$ & $26.71 \pm 0.01^{\mathrm{aA}}$ \\
\hline & After & $7.06 \pm 0.09^{\mathrm{aB}}$ & VA & $0.013 \pm 0.001^{\mathrm{aB}}$ & $23.13 \pm 0.05^{\mathrm{aB}}$ \\
\hline \multirow{2}{*}{$\mathrm{P} 2$} & During & $6.92 \pm 0.02^{\mathrm{bA}}$ & VA & $0.023 \pm 0.001^{\mathrm{bA}}$ & $26.57 \pm 0.05^{\mathrm{abA}}$ \\
\hline & After & $6.57 \pm 0.05^{\mathrm{bB}}$ & VA & $0.033 \pm 0.001^{\mathrm{bB} *}$ & $23.61 \pm 0.17^{\mathrm{bB}}$ \\
\hline \multirow{2}{*}{ P3 } & During & $6.87 \pm 0.02^{\mathrm{bA}}$ & VA & $0.020 \pm 0.001^{\mathrm{cA}}$ & $26.33 \pm 0.05^{\mathrm{bA}}$ \\
\hline & After & $7.07 \pm 0.01^{\mathrm{aB}}$ & VA & $0.023 \pm 0.001^{\mathrm{cB}}$ & $23.43 \pm 0.11^{\mathrm{bB}}$ \\
\hline \multirow{2}{*}{ P4 } & During & $7.05 \pm 0.03^{\mathrm{cA}}$ & VA & $0.020 \pm 0.001^{\mathrm{cA}}$ & $26.51 \pm 0.00^{\mathrm{abA}}$ \\
\hline & After & $7.19 \pm 0.01^{\mathrm{cB}}$ & VA & $0.026 \pm 0.001^{\mathrm{dB}}$ & $23.33 \pm 0.15^{\mathrm{abB}}$ \\
\hline \multicolumn{2}{|c|}{ Conama No 357/2005 } & $6.00-9.01$ & $\leq 3.7$ & $\leq 0.1$ & - \\
\hline
\end{tabular}

P1: River headwater; P2: Residential condominium; P3: The trench and the roundabout construction; P4: River mouth. VA: Virtually Absent.

Values with the same letter do not differ statistically among themselves; lowercase is used for the comparison among the four sampling points at each collection time, and uppercase for the comparison between the times of each collection point by Tukey test with a significance level of $5 \%, \mathrm{n}=3$.

BOD is an indicator parameter related to the amount of oxygen required in an aquatic environment for a microorganism's respiration over the consumption of organic substances, which are directly associated with the presence of animal and food waste or residential/industrial discharge of untreated sewage introduced into the aquatic environment (Oliveira et al., 2012). In this study, the values ranged from 12.78 to $68.33 \mathrm{mg} \mathrm{L}^{-1 ;} \mathrm{O}_{2}$ differed statistically $(\mathrm{p}<0.05)$ (Figure 2$)$ between the sample points. During the trench and roundabout construction, it could be seen that the values of the BOD, the DO and oils and greases (Figure 2) at any collection point were in disagreement with the values established by legislation $\left(\mathrm{BOD} \leq 5 \mathrm{mg} \mathrm{L}^{-1} \mathrm{O}_{2} ; \mathrm{DO} \geq 5 \mathrm{mg} \mathrm{L}^{-1} \mathrm{O}_{2}\right.$; oils and greases = virtually absent $)($ CONAMA, 2005). A similar phenomenon was observed by Sekabira et al. (2010), which showed values higher than the limit of local legislation (BOD $\leq 50 \mathrm{mg} \mathrm{L}^{-1}$ - National Environment Management Authority - NEMA), mainly due to the discharge of industrial effluents in the Nakivubo stream (Kampala - Uganda). 


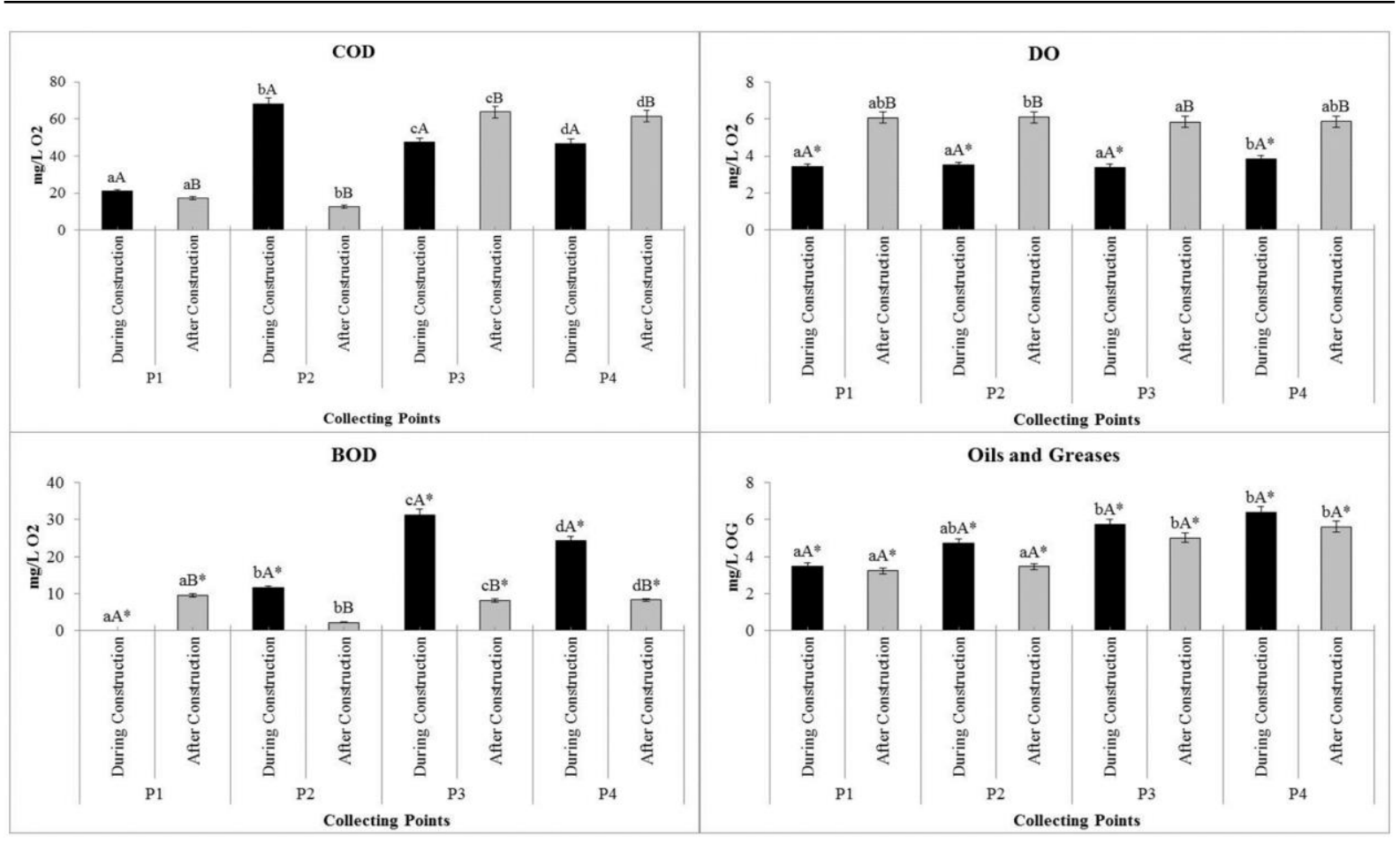

Figure 2. Average and standard deviation of physicochemical parameters analyzed for the different points of the Trincheira's River, during and after the construction of the road infrastructure.

P1: River headwater; P2: Residential condominium; P3: The construction site of the trench and roundabout; P4: River mouth. COD: chemical oxygen demand; BOD: biochemical oxygen demand; DO: dissolved oxygen. * Data different from those established by law $\mathrm{N}^{\circ} 357$ of 2005 from CONAMA for Class II. Values with the same letter do not differ statistically among themselves; lowercase is used for comparison among the four sampling points in each collection time, and uppercase for the comparison between the times of each collection point by Tukey test with a significance level of $5 \%$.

The lowest levels of DO $\left(3.4-3.87 \mathrm{mg} \mathrm{L}^{-1}\right)$ related to the presence of organic matter or similar synthetic compounds in the river waters. A similar study carried out in the Dourados and Brilhante Rivers by Sposito et al. (2019) related the low OD values found (3.66 - $4.86 \mathrm{mg} \mathrm{L}^{-1} \mathrm{O} 2$ ) to the intense urbanization process (domestic effluent disposal) and agriculture (pesticides and agrochemicals). Arpine and Gayane (2016), studying the water of river Akhuryan (Armenia), observed higher DO values $\left(10.3 \mathrm{mg} \mathrm{L}^{-1} \mathrm{O}_{2}\right)$ and lower BOD $\left(2.8 \mathrm{mg} \mathrm{L}^{-1} \mathrm{O}_{2}\right)$ and $\mathrm{COD}\left(10.5 \mathrm{mg} \mathrm{L}^{-1} \mathrm{O}_{2}\right)$ values than those of the present study, aforenamed. However, the Akhuryan waters possess a great potential for self-depuration, because its riverbed features a shapeless rocky profile when, adversely, the Trincheira's River waters has a reduced and uniform flow rate. In the present study, it was possible to verify a significant increase of the DO concentration after the roundabout construction (Figure 2), setting the values according those recommended by CONAMA (2005). This increase in the DO concentration is possibly due to a reduction in the release of organic substances, such as oils and greases, after the work ended.

According to CETESB (2009), the decomposition process of oils and greases, could reduce dissolved oxygen and the contact surface between the water surface and the atmospheric air. In addition, the increase of BOD and COD concentration could lead to aesthetic and organoleptic problems on the course of the river as well as scum formation, eutrophication and bad smell.

According to Brazilian legislation (CONAMA, 2005), the presence of oils and greases in hydrous bodies should be null. In the present study, these compound were found at all sampled points, with contents ranging from 3.24 to $6.40 \mathrm{mg} \mathrm{L}^{-1}$ with significant difference $(\mathrm{p}<0.05)$ between the sampling points P1, P3 and P4 (Figure 2). This presence could imply a source of oil or synthetic derivative contamination, indicating pollution from urban waste, sewage 
disposal and accidental spills. Katukiza et al. (2015) have shown that domestic effluent water charges in the Bwaise III (Kampala - Uganda) showed concentrations of oils and greases above that established by local legislation $\left(10 \mathrm{mg} \mathrm{L}^{-1}\right)$, as well as the situation found in the present study. Highway vehicles release particulates and synthetic lubricants, which are leached by surface runoff during precipitation events until they reach the river. Van Bohemen and Janssen Van de Laak (2003) found similar values for the concentration of oils and derivatives (3.0 - 8.0 mg L-1) in runoff waters on national, provincial and municipal roads in Holanda. Moreover, during the roundabout construction, there was a high incidence of large machinery moviment, such as excavators, bulldozers and dump trucks, which could have accidentally spilled oil, grease, and tar.

Physicochemical data corroborate with those found in the immobility/mortality test with the bioindicator A. salina (Figure 3). The waters of Trincheira's River had a high mortality rate at the point of the trench and the roundabout construction after the end of the construction (P3) (17\% mortality) (Figure 3). Maddela et al. (2016), studying the removal of petroleum hydrocarbons, showed that the higher the concentration of these petrochemical derivatives, the greater was the mortality ( $\approx 33,5 \%$ - exposure for $24 \mathrm{~h})$ of the $A$. salina shellfish.

The statistical data from the immobility/mortality test did not show significant toxicological effect of the water samples, during or after the construction of road infrastructure, because the mortality of organisms exposed to water samples of all four points of the river was statistically similar to negative control mortality.

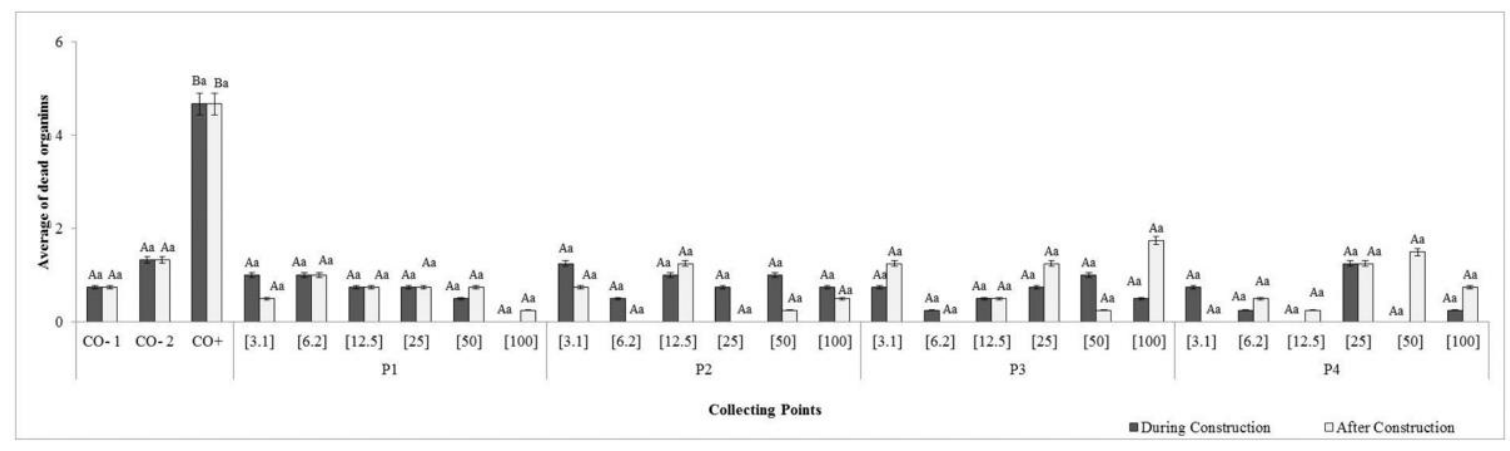

Figure 3. Average numbers of dead organisms obtained during and after the road infrastructure construction for different concentrations of water samples from Trincheira's River. $\mathrm{CO}^{-} 1$ : Negative control with saline solution. $\mathrm{CO}^{-} 2$ : Negative control with mineral water. $\mathrm{CO}^{+}$: Positive control. P1: River headwater; P2: Residential condominium; P3: The construction site of the trench and roundabout; $\mathrm{P} 4$ : The river mouth.

Percentages with the same letters do not differ statistically among themselves; uppercase is used for comparison within the same collection time, and lowercase for comparison between the two times of collection, by Tukey test with a significance level of $5 \%$.

Additionally, changes in toxicity were not observed during or after the road construction for any evaluated point, because the average number of dead/still organisms was statistically similar. Similar results were found by Vaz et al. (2010), who studied the toxicity of Babitonga Bay (Santa Catarina, Brazil), also with the A. salina bioindicator. The data showed that the vast majority of the evaluated points was not toxic to the micro shellfish.

Components in gasoline and diesel fuel, such as benzene and benzo (a) pyrene, are carcinogenic compounds, while the toluene, ethylbenzene, and xylene are classified as toxic. However, when some of these derivatives are poured directly into the water, they have a rapid volatilization, with little tendency to adsorb sediments or to hydrolyze (Finotti et al. 2001), which possibly has resulted in lower acute toxicity of water samples from the Trincheira's River, contaminated by oils and greases. 
No cytotoxicity was observed by $A$. cepa bioindicator during the trench and roundabout construction. Data in Figure 4 show that there was no statistical difference between the mitotic index of the negative control at the time of sampling (Co-Oh, Tr-24h, and Re-24 h) and the groups treated with water samples collected from all points. When sampling times within the same group were compared, control or treaty, no statistical difference was found.

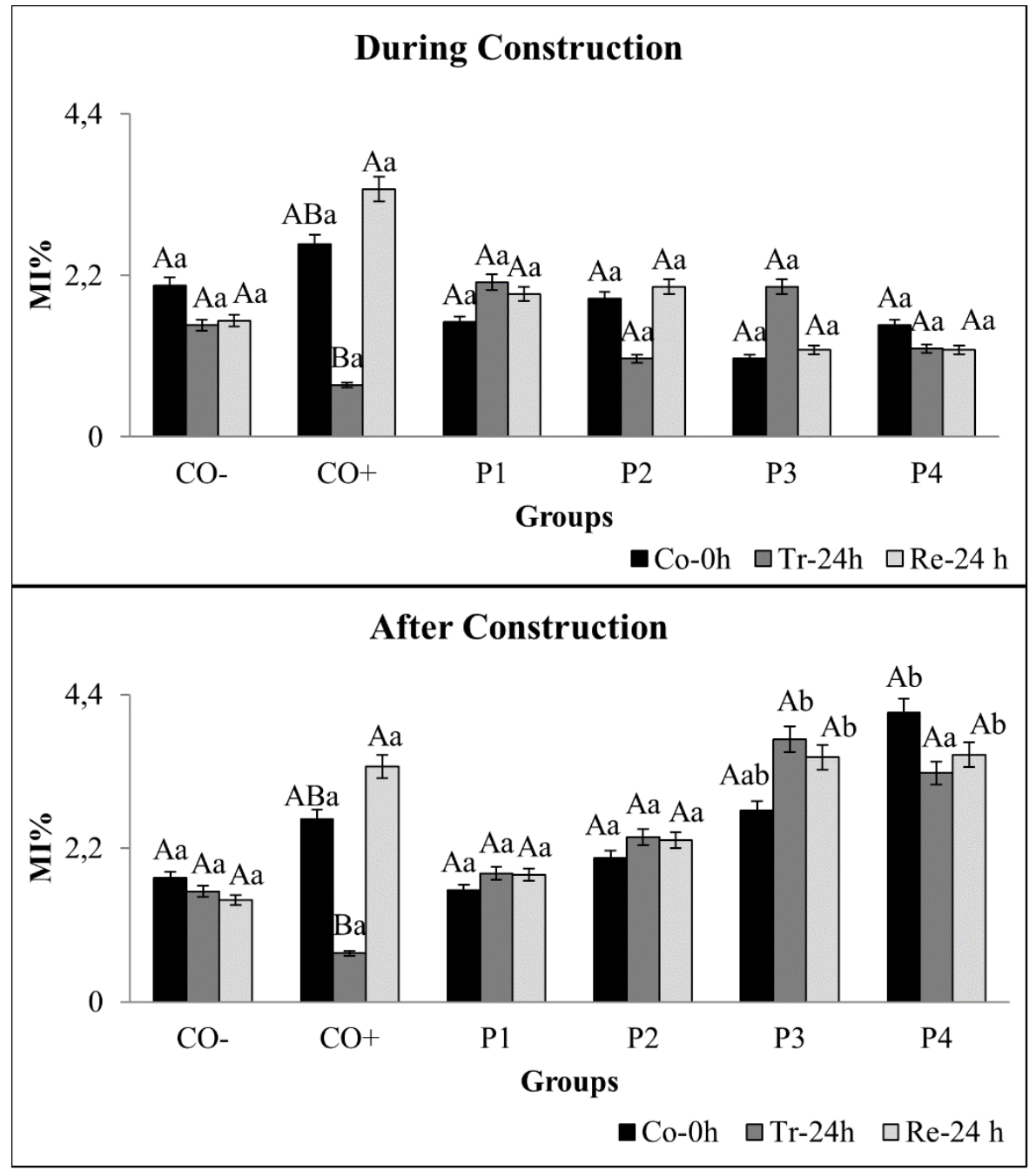

Figure 4. Percentage of Mitotic Indexes (MI) obtained during and after the construction of road infrastructure for water samples from Trincheira's River. $\mathrm{CO}^{-}$: Negative control. $\mathrm{CO}^{+}$: Positive control. P1: River headwater; P2: Residential condominium; P3: The trench and roundabout construction; P4: The river mouth. Sampling time: 0 time $=\mathrm{Co}-0 \mathrm{~h}$, Treatment 24 hours $=\mathrm{Tr}$ $24 \mathrm{~h}$, Recovery 24 hours $=\mathrm{Re}-24 \mathrm{~h}$. Percentages with the same three letters do not differ statistically among themselves; uppercase is used for the comparison between three sampling times within the same group or control, lowercase for comparison between each sampling time of the negative control with the same time of each group treated, by Tukey test with a significance level of 5\%.

The absence of A. cepa cytotoxicity, was also found in waters contaminated with petrochemical derivatives (leaked from a pipeline) (Leme and Marin-Morales, 2008) and effluents from refineries (Gupta and Ahmad, 2012). Similar results, using the same test system as the present study, were found on the surface waters of the Sava River (Croatia) (Radic et al., 2010), on the waters from Ribeirões Varginha River (Califórnia-Paraná-Brazil) and Tabatinga

\section{IPABH}

Rev. Ambient. Água vol. 14 n. 4, e2360 - Taubaté 2019 
River (Mandaguari-Paraná-Brasil) (Ferreira et al., 2012), and on the waters from the Peixe River collected in the cities of Garça, Tupã, Flórida Paulista and Ouro Verde (São Paulo-Brazil) (Costa et al., 2015), which also received agricultural, industrial and urban effluents along their courses. Morphological changes and chromosomal alterations were also not observed when exposed to the waters of Trincheira's River, similar to work by Ferreira et al. (2012).

After the road construction, the data of cytotoxicity (Figure 4) show that the groups treated with the waters from Trincheira's River showed percentages of mitotic indexes progressively larger, from 1 to $4(\mathrm{P} 1=1.84 \%, \mathrm{P} 2=2.36 \%, \mathrm{P} 3=4.00 \%, \mathrm{P} 4=3.28 \%)$. However, only Point 3 (site of the trench and roundabout construction) (24 hours) showed increases in the percentage of mitotic index statistically different from the negative control $(24$ hours $=1.58 \%)$ and P1. The values of physicochemical analysis were supported by those data. Points 3 and 4 presented the highest values of COD and mitotic indexes and smaller levels of DO when compared to other collection points.

The COD of Points 3 and 4 (site of the road construction and the river mouth) presented elevated levels from the first to the second collection (Figure 2). The change from wet weather to the dry weather could cause an increase in the level of contaminants, possibly, due to the decrease in the flow of the river (Kibena et al., 2014). After the roundabout construction, the water sampling was performed during a drier season (Autumn), resulting in a lower flow rate when compared to the headwater (first collection) at the moment the Trincheira's River was being piped in.

Similar to the studied data, the evaluation of Quatorze River, located in the rural municipality of Francisco Beltrão, showed that three points of this river were not cytotoxic to the A. сера bioindicator. One point presented statistical increase of cell proliferation and one point a greater organic load in the physicochemical analyses (Düsman et al., 2014). Gomes et al. (2015) also used the. A. cepa to study the cytotoxicity of the Guandu River (Rio de JaneiroBrazil), contaminated by urban and industrial effluents, and there were increased percentages of mitotic indexes of the onions exposed to these waters.

\section{CONCLUSIONS}

The data from this study indicate changes in some physicochemical parameters analyzed; in particular, oils and greases, biochemical oxygen demand and dissolved oxygen, close to the road infrastructure. Toxicology tests showed an increase in the number of dead A. salina and in the percentage of mitotic index of the A. cepa roots, from the headwater to the river mouth. It was most evident at the collection point of the trench and the roundabout construction for both bioindicators.

Therefore, awareness and regulatory measures are necessary to oversee activities performed on the water bodies' shores and environs, to ensure a harmonious relationship between human activities and the ecosystem.

\section{ACKNOWLEDGEMENTS}

To the Federal Technological University of Paraná, Francisco Beltrão-Paraná-Brazil.

\section{REFERENCES}

ABNT. Nbr 13373: Ecotoxicologia Aquática - Toxicidade crônica - Método de ensaio com Ceriodaphnia Ssp (Crustacea, Cladocera). 3. ed. Rio de Janeiro, 2010. 18 p.

APHA; AWWA; WEF. Standard Methods for the examination of water and wastewater. $22^{\text {nd }}$ ed. Washington, 2012.

Rev. Ambient. Água vol. 14 n. 4, e2360 - Taubaté 2019 
ARPINE, H.; GAYANE, S. Determination of background concentrations of hydrochemical parameters and water quality assessment in the Akhuryan river basin (Armenia). Physics and Chemistry of the Earth, v. 94, p. 2-9, 2016. https://doi.org/10.1016/j.pce.2016.03.011

AVVANNAVAR, S. M.; SHRIHARI, S. Evaluation of water quality index for drinking purposes for river Netravathi, Mangalore, South India. Environmental Monitoring and Assessment, v. 143, p. 279-290, 2008. https://doi.org/10.1007/s10661-007-9977-7

CETESB. Qualidade das águas interiores do estado de São Paulo. 2009. Available at: http://www.cetesb.sp.gov.br/agua/aguas-superficiais/35-publicacoes-/-relatorios. Access in: Dec. 2018.

CONAMA (Brasil). Resolução n 357 de 17 de março de 2005. Dispõe sobre a classificação dos corpos de água e diretrizes ambientais para o seu enquadramento, bem como estabelece as condições e padrões de lançamento de efluentes, e dá outras providências. Diário Oficial [da] União: seção 1, Brasília, DF, n. 053, p. 58-63, 18 mar. 2005.

COSTA, A. C.; DOMINGUES, G.; DÜSMAN, E.; ALMEIDA, I. V.; VICENTINI, V. E. P. V. Citotoxicidade das águas do Rio do Peixe (São Paulo-Brasil), em células meristemáticas de raiz de Allium cepa L. Bioscience Journal, v. 31, n. 1, p. 248-258, 2015. https://doi.org/10.14393/BJ-v31n1a2015-15069

DÜSMAN, E.; LUZZA, M.; SAVEGNAGO, L.; LAUXEN, D.; VICENTINI, V. E. P., TONIAL, I. B.; SAUER, T. P. Allium cepa L. as a bioindicator to measure cytotoxicity of surface water of the Quatorze river, located in Francisco Beltrão, Paraná, Brazil. Environmental Monitoring and Assessment, v. 186, p. 1793-1800, 2014. https://doi.org/10.1007/s10661-013-3493-8

FATMA, F.; VERMA, S.; KAMAL, A.; SRIVASTAVA, A. Monitoring of morphotoxic, cytotoxic and genotoxic potential of mancozeb using Allium assay. Chemosphere, v. 195, p. 864-870, 2018. https://doi.org/10.1016/j.chemosphere.2017.12.052

FERREIRA, C. F.; FRUEH, A. B.; DUSMAN, E.; HECK, M. C.; VICENTINI, V. E. P. Avaliação da citotoxicidade das águas dos ribeirões varginha (Califórnia-Pr) e Tabatinga (Mandaguari-Pr), em Allium cepa L. Sabios-Revista Saúde e Biologia, v. 7, n. 2, p. 46$54,2012$.

FINOTTI, A. R.; RODRIGUEZ, M. T. R.; CAICEDO, N. O. L. Contaminações subterrâneas com combustíveis derivados de petróleo: Toxicidade e a legislação brasileira. Revista Brasileira De Recursos Hídricos, v. 6, n. 2, p. 29-46, 2001.

FISKESJÖ, G. The Allium test as a standard in environmental monitoring. Hereditas, v. 102, n. 1, p. 99-112, 1985. https://doi.org/10.1111/j.1601-5223.1985.tb00471.x

FRANCISCO BELTRÃO. Perfil do Município. Francisco Beltrão, 2012. Available at: http://franciscobeltrao.pr.gov.br/departamentos/turismo/a-secretaria/economiatecnologia/perfil-do-municipio/attachment/perfil-do-municipio-2012-2/. Access in: Apr. 2016 .

FRONTALINI, F.; COCCIONI, R. Benthic Foraminífera as bioindicators of pollution: A review of italian research over the last three decades. Revue ae Micropaleontology, v. 54, n. 2, p. 115-127, 2011. https://doi.org/10.1016/j.revmic.2011.03.001

Rev. Ambient. Água vol. 14 n. 4, e2360 - Taubaté 2019 
GAN, H.; ZHUO, M.; LI, D.; ZHOU, Y. Quality characterization and impact assessment of highway runoff in the urban and rural area of Guangzhou, China. Environmental Monitoring and Assessment, v. 140, p. 147-159, 2008. https://doi.org/10.1007/s10661007-9856-2

GOMES, J. V.; TEIXEIRA, J. T. S.; LIMA, V. M.; BORBA, H. R. Induction of cytotoxic and genotoxic effects of Guandu river waters in the Allium cepa system. Revista Ambiente \& Água, v. 10, n. 1, p. 48-58, 2015. http://dx.doi.org/10.4136/ambi-agua.1487

GUERRA, R. Ecotoxicological and chemical evaluation of phenolic compounds in industrial effluents. Chemosphere, v. 44, n. 8, p. 1737-1747, 2001. https://doi.org/10.1016/S00456535(00)00562-2

GUPTA, A. K.; AHMAD, M. Assessment of the cytotoxic and genotoxic potential of refinery waste effluent using plant, animal, and bacterial systems. Journal of Hazardous Materials, v. 201-202, p. 92-99, 2012. https://doi.org/10.1016/j.jhazmat.2011.11.044

GUPTA, N.; PANDEY, P.; HUSSAIN, P. Effect of physicochemical and biological parameters on the quality of river water of Narmada, Madhya Pradesh, India. Water Science, v. 31, p. 11-23, 2017. https://doi.org/10.1016/j.wsj.2017.03.002

IAPAR. Agrometeorologia - Dados pluviométricos diários. Available at: http://www.iapar.br. Access in: Nov. 2016.

KATUKIZA, A. Y.; RONTELTAP, M.; NIWAGABA, C. B.; KANSIIME, F.; LENS, P. N. L. Grey water characterisation and pollutant loads in an urban slum. International Journal of Environmental Science and Technology, v. 12, p. 423-436, 2015. https://doi.org/10.1007/s13762-013-0451-5

KIBENA, J.; NHAPI, I.; GUMINDOGA, W. Assessing the relationship between water quality parameters and changes in land-use patterns in the upper Manyame river, Zimbabwe. Physics and Chemistry of The Earth, v. 67-69, p. 153-163, 2014. https://doi.org/10.1016/j.pce.2013.09.017

KUHLMANN, M. L.; BRANDIMARTE, A. L.; SHIMIZU, G. Y.; ANAYA, M. Invertebrados bentônicos como indicadores de impactos antrópicos sobre ecossistemas aquáticos continentais. In: MAIA, N. B.; MARTOS, B.; HENRY, L. (Eds). Indicadores ambientais: Conceitos e aplicações. São Paulo: Educ/Comped/Inep, 2001.

LEME, D. M.; MARIN-MORALES, M. A. Chromosome aberration and micronucleus frequencies in Allium cepa cells exposed to petroleum polluted water-a case study. $\begin{array}{llllll}\text { Mutation } & \text { Research, } & \text { v. } & 650, & \text { p. } & 80-86,\end{array}$ https://doi.org/10.1016/j.mrgentox.2007.10.006

LUÍZ, Â. M. E.; PINTO, M. L. C.; SCHEFFER, E. Parâmetros de cor e turbidez relacionados aos usos do solo e à morfometria da bacia hidrográfica do Rio Taquaral, São Mateus do Sul-Pr. Revista Caminhos da Geografia, v. 24, p. 290-310, 2012.

MADDELA, N. R.; BRUGOS, R.; KADIYALA, V.; CARRION, A. R.; BANGEPPAGARI, M. Removal of petroleum hydrocarbons from crude oil in solid and slurry phase by mixed soil microorganisms isolated from ecuadorion oil fields. International Biodeterioration \& Biodegradation, v. 108, p. 85-90, 2016. https://doi.org/10.1016/j.ibiod.2015.12.015

Rev. Ambient. Água vol. 14 n. 4, e2360 - Taubaté 2019 
MORAES, S. S. M.; SANTOS, E. M. Avaliação de impactos ambientais (AIA): instrumento importante na sustentabilidade dos projetos rodoviários. Revista da Farn, v. 3, n. 1-2, p. 45-58, 2004.

OLIVEIRA, J. P. W.; SANTOS, R. N.; BOEIRA, J. M. Genotoxicidade e análises físicoquímicas das águas do Rio Sinos (RS) usando Allium cepa e Eichhornia crassipes como bioindicadores. Biochemistry and Biotechnology Reports, v. 1, n. 1, p. 15-22, 2012. http://dx.doi.org/10.5433/2316-5200.2012v1n1p15

RADIC, S.; STIPANICEV, D.; VUJCIC, V.; RAJCIC, M.; SIRAC, S.; PEVALEK-KOZLINA, B. The evaluation of surface and wastewater genotoxicity using the Allium cepa Test. Science of the Total Environmental, v. 408, p. 1228-1233, 2010. https://doi.org/10.1016/j.scitotenv.2009.11.055

RAHMAN, I. M. M.; ISLAM, M. M.; HOSSAIN, M. M.; HOSSAIN, M. S.; BEGUM, Z. A.; CHOWDHURY, D. A.; CHAKRABORTY, M. K.; RAHMAN, M. A.; NAZIMUDDIN, M.; HASEGAWA, H. Stagnant surface water bodies (SSWBs) as an alternative water resource for the Chittagong metropolitan area of Bangladesh: physicochemical characterization in terms of water quality indices. Environmental Monitoring and Assessment, v. 173, p. 669-https://doi.org/10.1007/s10661-010-1414-7 684, 2011

SEKABIRA, K.; ORIGA, H. O.; BASAMBA, T. A.; MUTUMBA, G.; KAKUDIDI, E. Heavy metal assessment and water quality values in urban stream and rain water. International Journal of Environmental Science and Technology, v. 7, p. 759-770, 2010. https://doi.org/10.1007/BF03326185

SILVA, J.; HEUSER, V.; ANDRADE, V. Biomonitoramento ambiental. In: SILVA, J.; ERDTMANN, B.; HENRIQUES, J. A. P. (Eds.). Genética Toxicológica. Porto Alegre: Alcance, 2003 p. 166-180.

SILVA, L.; HELDWEIN, C.; REETZ, L.; HORNER, R.; MALLMANN, C.; HEINZMANN, B. Composição química, atividade antibacteriana in vitro e toxicidade em artemia salina do óleo essencial das inflorescências de Ocimum gratissimum L., lamiaceae. Revista Brasileira de Farmacognosia, v. 20, n. 5, p. 700-705, 2010. https://dx.doi.org/10.1590/S0102-695X2010005000010

SPOSITO, J. C. V.; FRANCISCO, L. F. V.; CRISPIM, B. A.; DANTAS, F. G. S.; SOUZA, J. P.; VIANA, L. F.; SOLÓRZANO, J. C. J.; OLIVEIRA, K. M. P.; BARUFATTI, A. Influence of Land Use and Cover on Toxicogenetic Potential of Surface Water from Central West Brazilian Rivers. Archives of Environmental Contamination and Toxicology, v. 76, p. 483-495, 2019. https://doi.org/10.1007/s00244-019-00603-2

TAVARES, R. D. Avaliação físico-química e ecotoxicológica de efluentes provenientes de estações de tratamento de esgoto. Revista Ibero-Americana de Ciências Ambientais, v. 5, n. 1, p. 303-318, 2014. https://doi.org/10.6008/SPC2179-6858.2014.001.0022

VAN BOHEMEN, H. D.; JANSSEN VAN DE LAAK, W. H. The Influence of Road Infrastructure and Traffic on Soil, Water, and Air Quality. Environmental Management, v. 31, p. 50-68, 2003. https://doi.org/10.1007/s00267-002-2802-8

VAZ, C.; OLIVEIRA, T. M. N. O.; BÖHM, R. F. S.; SPITZNER, E. C.; SIMM, M.; BARROS, V. G. Use of Artemia salina to identify sites with the risk of contamination in the waters of Babitonga Bay. Toxicology Letters, v. 196, p. 37-351, 2010. http://dx.doi.org/10.1016\%2Fj.toxlet.2010.03.423 
VON SPERLING, M. Princípios de tratamento biológico de águas residuárias: introdução à qualidade das águas e ao tratamento de esgotos. Belo Horizonte, 2005.

YALCUK, A.; POSTALCIOGLU, S. Evaluation of pool water quality of trout farms by fuzzy logic: monitoring of pool water quality for trout farms. International Journal of Environmental Science and Technology, v. 12, p. 1503-1514, 2015. https://doi.org/10.1007/s13762-014-0536-9 